\title{
OSM is overexpressed in knee osteoarthritis and Notch signaling is involved in the effects of OSM on MC3T3-E1 cell proliferation and differentiation
}

\author{
J. NI, X.M. YUAN, Q. YAO and L.B.PENG \\ Department of Orthopaedics, Beijing Shijitan Hospital, Capital Medical University, Beijing 100038, P.R. China
}

Received October 20, 2014; Accepted March 23, 2015

DOI: $10.3892 /$ ijmm.2015.2168

\begin{abstract}
Knee osteoarthritis (OA) is the most prevalent type of OA and the cytokine, oncostatin M (OSM), may contribute to the pathogenesis of OA. However, the exact role of OSM in the development of knee OA and the underlying mechanisms are not yet fully understood. This study was designed to detect the expression of OSM in the synovial tissue of patients with knee OA. Furthermore, we investigated whether Notch signaling is involved in the effects of OSM on MC3T3-E1 cell proliferation and differentiation. The synovial tissue of the knee joint was collected from 32 patients with knee OA. We detected OSM mRNA and protein expression (by RT-qPCR and western blot analysis, respectively) in the synovial tissue of the knee joint, and the expression level of OSM was higher in the patients with knee OA compared with the controls. MTT assay was used in the in vitro experiments to determine MC3T3-E1 cell proliferation, and cell differentiation was determined by measuring alkaline phosphatase (ALP) activity and osteocalcin (OCN) expression. The results from our in vitro experiments revealed that OSM induced bone formation by increasing osteoblast cell proliferation and differentiation. In addition, the expression levels of Notch ligand, receptor and target gene, including Delta-like 1 (D111), Notch homolog 1 (Notch1) and Hes family bHLH transcription factor 1 (Hes1) were decreased following treatment with OSM in a time-dependent manner in the MC3T3-E1 cells. A D111 overexpression vector was transfected into the cells to activate Notch signaling, and the results revealed that the activation of Notch signaling attenuated the effects of OSM on MC3T3-E1 cell proliferation and differentiation. In conclusion, our data demonstrate that elevated levels of OSM in synovial tissue induce bone formation by increasing osteoblast cell proliferation and differentiation. The Notch signaling pathway was found to be one of the signaling pathways that inhibit OSM-induced MC3T3-E1 cell proliferation and differentiation. The findings of this study may broaden our
\end{abstract}

Correspondence to: Professor Q. Yao, Department of Orthopaedics, Beijing Shijitan Hospital, Capital Medical University, 10 Tieyi Road, Beijing 100038, P.R. China

E-mail: qyao1122@163.com

Key words: knee osteoarthritis, oncostatin-M, Notch signaling understanding of the mechanisms behing the role of OSM in the development of knee OA.

\section{Introduction}

Osteoarthritis (OA) is a musculoskeletal disorder (1) accounting for $3 \%$ of total number of years of living with a disability, particularly in the elderly $(2,3)$. Knee OA is the most prevalent type of OA (4). It is characterized by the progressive degeneration and structural disorder of the articular cartilage, resulting in loss of joint space, accompanied by marginal and central new bone formation (5).

Over the past 30 years, a number of cytokines have been identified to be involved in OA, particularly interleukin (IL)-1 and IL-6 (6). Oncostatin M (OSM) is a glycoprotein which belongs to the IL- 6 family of cytokines. It was firstly purified and biochemically characterized for its anti-proliferative effects on the A375 human melanoma cell line (7). An increasing amount of evidence has indicated that OSM participates in a variety of biological activities, such as differentiation, inflammation, development and the enhancement of metastatic capacity (8-11).

Osteoblasts and stromal cells isolated from the subchondral femoral heads of patients with OA express OSM (12). Mice transfected with the OSM gene have been shown to develop prominent characteristics of arthritis, such as joint inflammation, bone cell apoptosis, chondrophyte formation and the depletion of articular cartilage proteoglycans (13). However, the exact role of OSM in the development of OA and the underlying mechanism are not yet fully understood. To the best of our knowledge, this study is the first to detect the expression of OSM in the synovial tissue of patients with knee OA. Furthermore, a new signaling pathway was found to participate in the effects of OSM on MC3T3-E1 cell proliferation and differentiation. This study may broaden our understanding of the mechanisms behind the role of OSM in the development of knee OA.

\section{Materials and methods}

Sample collection. The present study was approved by the Ethics Committee of Beijing Shijitan Hospital, Capital Medical University and all the patients provided informed written consent prior to participation in the study. The OA synovial tissue of the knee joint was obtained from 32 patients with OA who underwent total knee replacement and arthroscopy. Normal control 
synovial tissue of the knee joint was obtained from 12 patients with a discoid meniscus. The tissues were immediately stored at $-80^{\circ} \mathrm{C}$ until use in western blot analysis and reverse transcriptionquantitative polymerase chain reaction (RT-qPCR).

Cell culture and transfection. The mouse osteoblast cell line, MC3T3-E1, was purchased from the American Type Culture Collection (Manassas, VA, USA). The cells were maintained in Dulbecco's modified Eagle's medium (DMEM) supplemented with $10 \%$ heat-inactivated fetal bovine serum (FBS) (both from Gibco-BRL Life Technologies, Grand Island, $\mathrm{NY}$, USA) at $37^{\circ} \mathrm{C}$ in a humidified atmosphere with $5 \% \mathrm{CO}_{2}$. OSM was purchased from R\&D Systems (Minneapolis, MN, USA) and was diluted with phosphate-buffered saline (PBS) into the indicated concentrations. The full-length cDNA fragment of the mouse Dll1 gene was amplified and cloned into the pEGFP-C1 vector (Clontech Laboratories, Inc., Mountain View, CA, USA) at the BglII and BamHI sites to generate the Dll1 overexpression vector. The Dll1 overexpression vector was transfected into the MC3T3-E1 cells using Lipofectamine 2000 (Invitrogen Life Technologies, Grand Island, NY, USA) following the manufacturer's instructions.

Measurement of alkaline phosphatase (ALP) activity. ALP activity was determined in the MC3T3-E1 cells in U/ml sample using an Alkaline Phosphatase Activity Colorimetric Assay kit (BioVision Inc., Mountain View Milpitas, CA, USA) according to the manufacturer's instructions. Briefly, the cells were homogenized in the assay buffer and centrifuged at 13,000 x g for $3 \mathrm{~min}$. Different volume of samples were added into a 96-well plate and assay buffer was used to increase the total volume to $80 \mu \mathrm{l}$. A total of $50 \mu \mathrm{l}$ of the $5 \mathrm{mM}$ pNPP solution was added to each well followed by incubation for $60 \mathrm{~min}$ at room temperature. A standard curve was created by the addition of $1 \mathrm{mM}$ pNPP $0,4,8,12,16$ and $20 \mu \mathrm{l}$ into a 96-well plate in duplicate to generate $0,4,8,12,16$ and $20 \mathrm{nmol} /$ well pNPP standard followed by the addition of $10 \mu \mathrm{l}$ of ALP enzyme solution to each well containing the pNPP standard. Subsequenlty, the reactions were terminated by the addition of $20 \mu \mathrm{l}$ Stop Solution and the optical density (OD) was measured at $405 \mathrm{~nm}$ using a microplate reader (Ascent 354; Thermo Labsystems, Waltham, MA, USA).

MTT assay. The MC3T3-E1 cells were seeded into a 96-well plate and allowed to grow for $24 \mathrm{~h}$. Following treatment with various concentrations of OSM $(5-100 \mathrm{ng} / \mathrm{ml})$ for the appropriate periods of time, $50 \mu \mathrm{l}$ MTT solution (Beyotime, Shanghai, China) were added to the well followed by incubation at $37^{\circ} \mathrm{C}$ for $4 \mathrm{~h}$. Formazin granules were dissolved with $150 \mu 1$ DMSO (Sigma, St. Louis, MO, USA) and the OD at $570 \mathrm{~nm}$ was measured using a microplate reader (Ascent 354; Thermo Labsystems).

$R T-q P C R$. Total RNA was isolated using TRIzol reagent (Invitrogen Life Technologies, Carlsbad, CA, USA). A total of $2 \mu \mathrm{g}$ of RNA was reverse transcribed using a cDNA synthesis kit (RevertAid ${ }^{\mathrm{TM}}$ First Strand cDNA Synthesis kit; Fermentas, Vilnius, Lithuania). Quantitative (real-time) PCR was performed using the SYBR PCR Master Mix (Applied Biosystems, Foster City, CA, USA) on the Applied Biosystems
7900HT Fast Real-Time PCR system. The relative expression level was calculated using the comparative $\mathrm{Ct}$ method.

Western blot analysis. Total protein was separated using ice-cold lysis buffer [1 mM EDTA, $20 \mathrm{mM}$ Tris- $\mathrm{HCl}$ (pH 7.5), $10 \mathrm{mg} / \mathrm{ml}$ soybean trypsin inhibitor, $15 \mathrm{mM} \mathrm{CHAPS}$, $0.05 \%$ Tween-20 and $10 \mathrm{mM}$ PMSF] and subjected to $10 \%$ sodium dodecyl sulfate-polyacrylamide gel electrophoresis. The separated proteins were transferred onto a PVDF membrane (EMD Millipore Corp., Billerica, MA, USA). The membrane was then blocked with $5 \% \mathrm{BSA}$ at $4^{\circ} \mathrm{C}$ overnight and incubated with antibodies against OSM (Cat. no. sc-50296), Notch homolog 1 (Notch1; Cat. no. sc-9170), Hes family bHLH transcription factor 1 (Hes1; Cat. no. sc-25392) (Santa Cruz Biotechnology, Inc., Santa Cruz, CA, USA), osteocalcin (OCN; Cat. no. ab93876), Delta-like 1 (Dll1; Cat. no. ab10554) (Abcam, Cambridge, MA, USA) and glyceraldehyde 3-phosphate dehydrogenase (GAPDH; Cat. no. 10494-1-AP) (Proteintech Group Inc., Chicago, IL, USA) at $37^{\circ} \mathrm{C}$ for $2 \mathrm{~h}$. After washing with PBS, the membrane was incubated with horseradish peroxidase (HRP)-labeled antibody (Cat. no. sc-2004) at $37^{\circ} \mathrm{C}$ for $1 \mathrm{~h}$. Immunoreactive bands were visualized using a chemiluminescence-based detection system (ECL Western Blotting Detection kit; Pierce Biotechnology, Inc., USA).

Statistical analysis. Data were shown as the means \pm SD of at least 3 independent studies. The Student's t-test was used to assess differences between 2 groups. P-values $<0.05$ were considered to indicate statistically significant differences.

\section{Results}

Expression of OSM in the synovial tissue of the knee joint. OSM mRNA and protein expression in the synovial tissue of the knee joint was detected by RTqPCR and western blot analysis. The synovial tissue of the knee joint obtained from patients with discoid menisci was used as a control (Fig. 1). The relative mRNA expression level of OSM was significantly increased in the patients with OA compared with the controls $(\mathrm{P}<0.01$; Fig. 1A). The results from western blot analysis revealed that the OSM protein expression level was also higher in the synovial tissue of patients with knee OA compared to that of the controls $(\mathrm{P}<0.01$; Fig. 1B).

Effect of OSM on MC3T3-E1 cell proliferation. Following 2 and 4 days of treatment with various concentrations of OSM, MC3T3-E1 cell proliferation was measured by MTT assay. We found that treatment with $5 \mathrm{ng} / \mathrm{ml} \mathrm{OSM}$ did not affect cell viability following 2 and 4 days of treatment $(\mathrm{P}>0.05)$. However, treatment with OSM at $10-100 \mathrm{ng} / \mathrm{ml}$ significantly increased MC3T3-E1 cell viability following 2 and 4 days of incubation (Fig. 2).

Effect of OSM on MC3T3-E1 cell differentiation. The MC3T3-E1 cells were incubated for 3 days with various concentrations of OSM, and the early- and middle-stage osteogenic markers, ALP activity and OCN expression, respectively, were then examined. Treatment with OSM did not induce ALP activity and OCN at the concentration of $5 \mathrm{ng} / \mathrm{ml}$. Treatment with OSM at $10-100 \mathrm{ng} / \mathrm{ml}$ induced ALP activity with the 

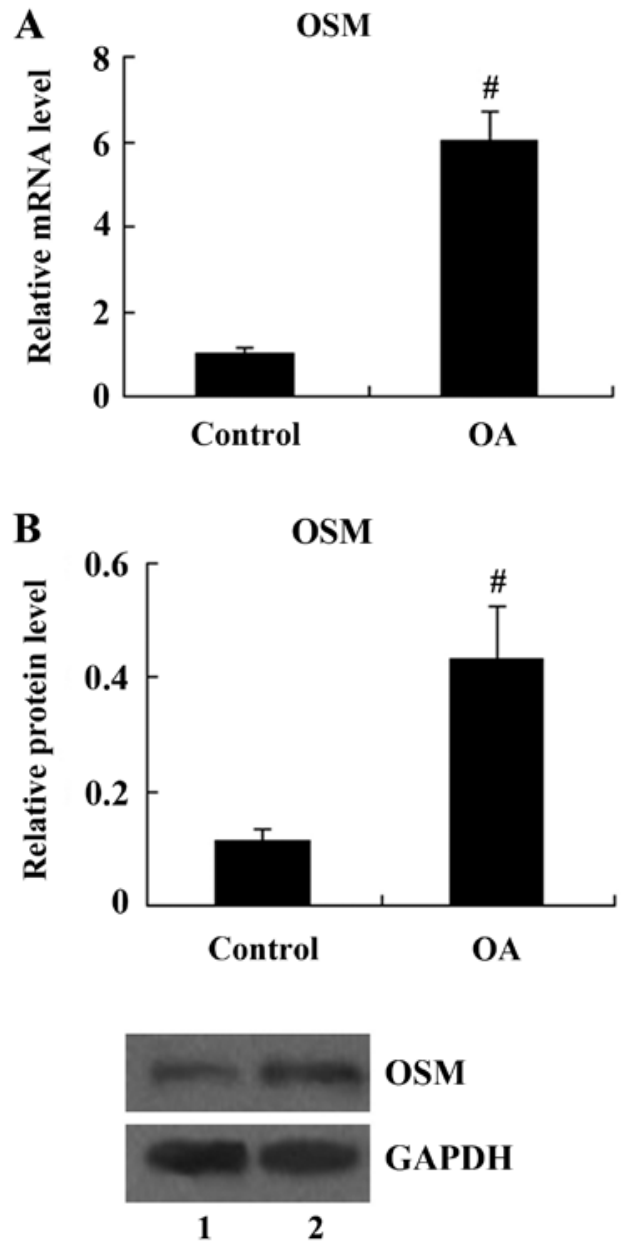

Figure 1. Expression of OSM. (A) mRNA and (B) protein expression in the synovial tissue of the knee joint in patients with $\mathrm{OA} .{ }^{.} \mathrm{P}<0.01$ vs. control. Lane 1 , control; lane 2, OA. OSM, oncostatin M; OA, osteoarthritis.

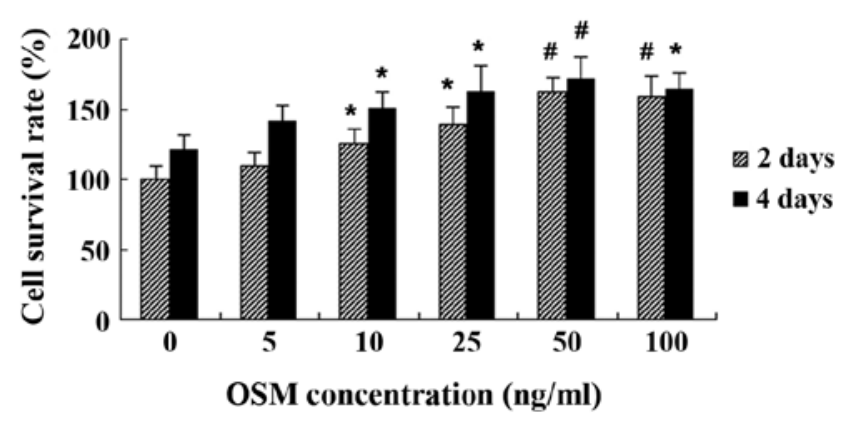

Figure 2. Effect of OSM on MC3T3-E1 cell proliferation. "P $<0.05$ and ${ }^{\text {"P }}$ < $<.01$ vs. $0 \mathrm{ng} / \mathrm{ml}$. OSM, oncostatin $\mathrm{M}$.

maximum effect (peak value) being observed at the dose of $50 \mathrm{ng} / \mathrm{ml}$ (Fig. 3). OCN mRNA and protein expressin were also induced following treatment with increasing concentrations of OSM. The increase in its expression was observed with OSM at the dose of 10-100 ng/ml (Fig. 4).

Effect of OSM on the expression of Notch signaling molecules. The MC3T3-E1 cells were incubated with $50 \mathrm{ng} / \mathrm{ml}$ OSM for 1-4 days, and the expression of Dl11, Notch1 and Hes1 was

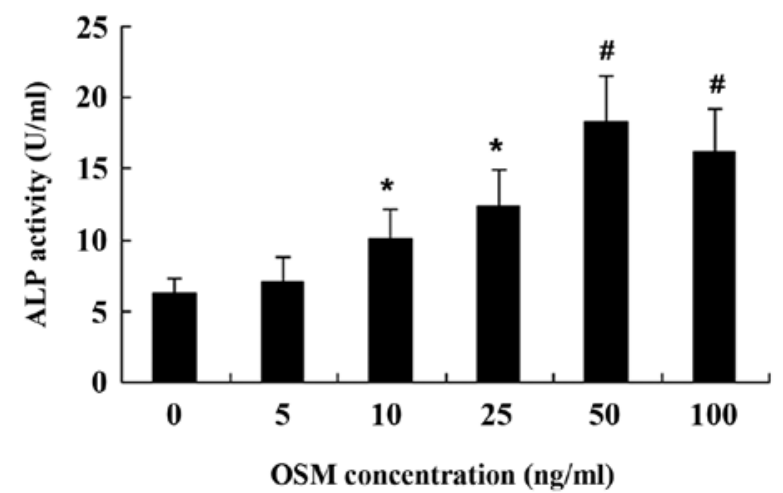

Figure 3. Effect of OSM on ALP activity. ${ }^{~} \mathrm{P}<0.05$ and ${ }^{\#} \mathrm{P}<0.01 \mathrm{vs} .0 \mathrm{ng} / \mathrm{ml}$. OSM, oncostatin M; ALP, alkaline phosphatase.
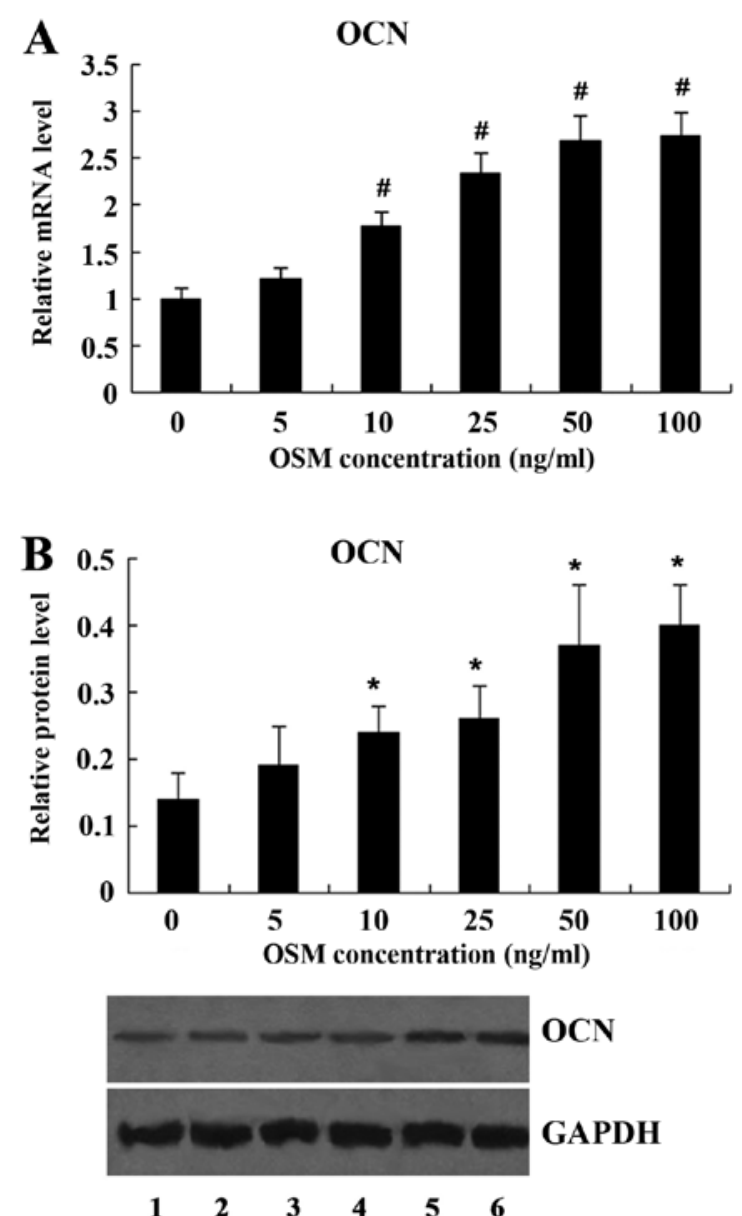

Figure 4. Effect of OSM on OCN (A) mRNA and (B) protein expression. ${ }^{*} \mathrm{P}<0.05$ and ${ }^{~} \mathrm{P}<0.01$ vs. $0 \mathrm{ng} / \mathrm{ml}$. Lane $1,0 \mathrm{ng} / \mathrm{ml}$ OSM; lane 2, $5 \mathrm{ng} / \mathrm{ml}$ OSM; lane 3, $10 \mathrm{ng} / \mathrm{ml}$ OSM; lane 4, $25 \mathrm{ng} / \mathrm{ml}$ OSM; lane 5, $50 \mathrm{ng} / \mathrm{ml} \mathrm{OSM}$; lane 6, $100 \mathrm{ng} / \mathrm{ml}$ OSM. OSM, oncostatin M; OCN, osteocalcin.

determined by western blot analysis. OSM at the concentration of $50 \mathrm{ng} / \mathrm{ml}$ inhibited the expression of Dll1, Notch1 and Hes1 following treatment for 1-4 days compared with the untreated cells (Fig. 5).

Activation of Notch signaling attenuates the effects of OSM on MC3T3-E1 cell proliferation. Following transfection with 

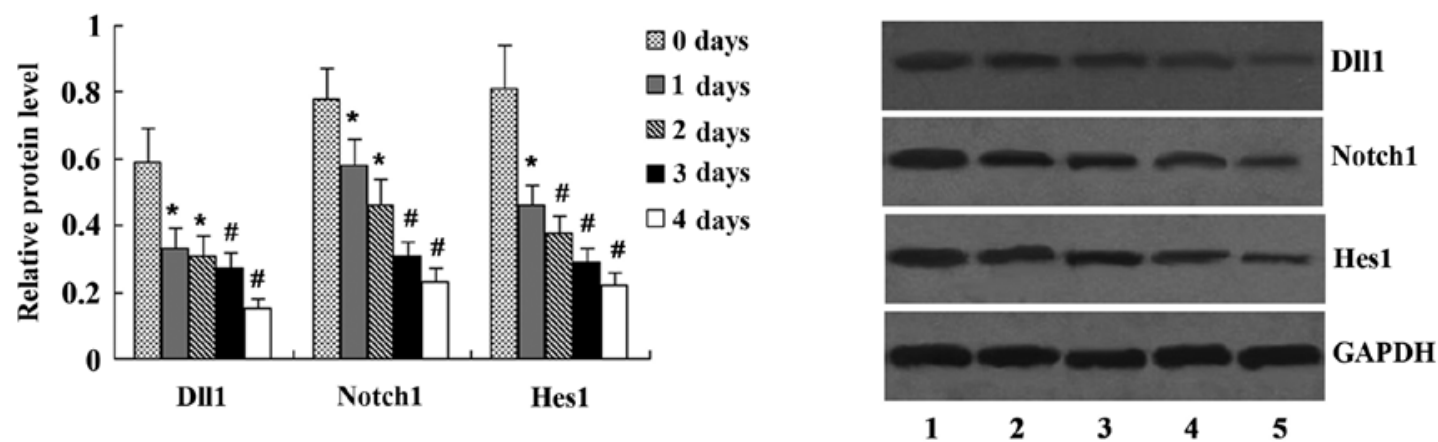

Figure 5. Effect of OSM on the protein expression of Notch signaling molecules. " $\mathrm{P}<0.05$ and ${ }^{\#} \mathrm{P}<0.01$ vs. 0 day. Lane 1, 0 day; lane 2, 1 day; lane 3, 2 days; lane 4 , 3 days; lane 5, 4 days. Dl11, Delta-like 1; Notch1, Notch homolog 1; Hes1, Hes family bHLH transcription factor 1.
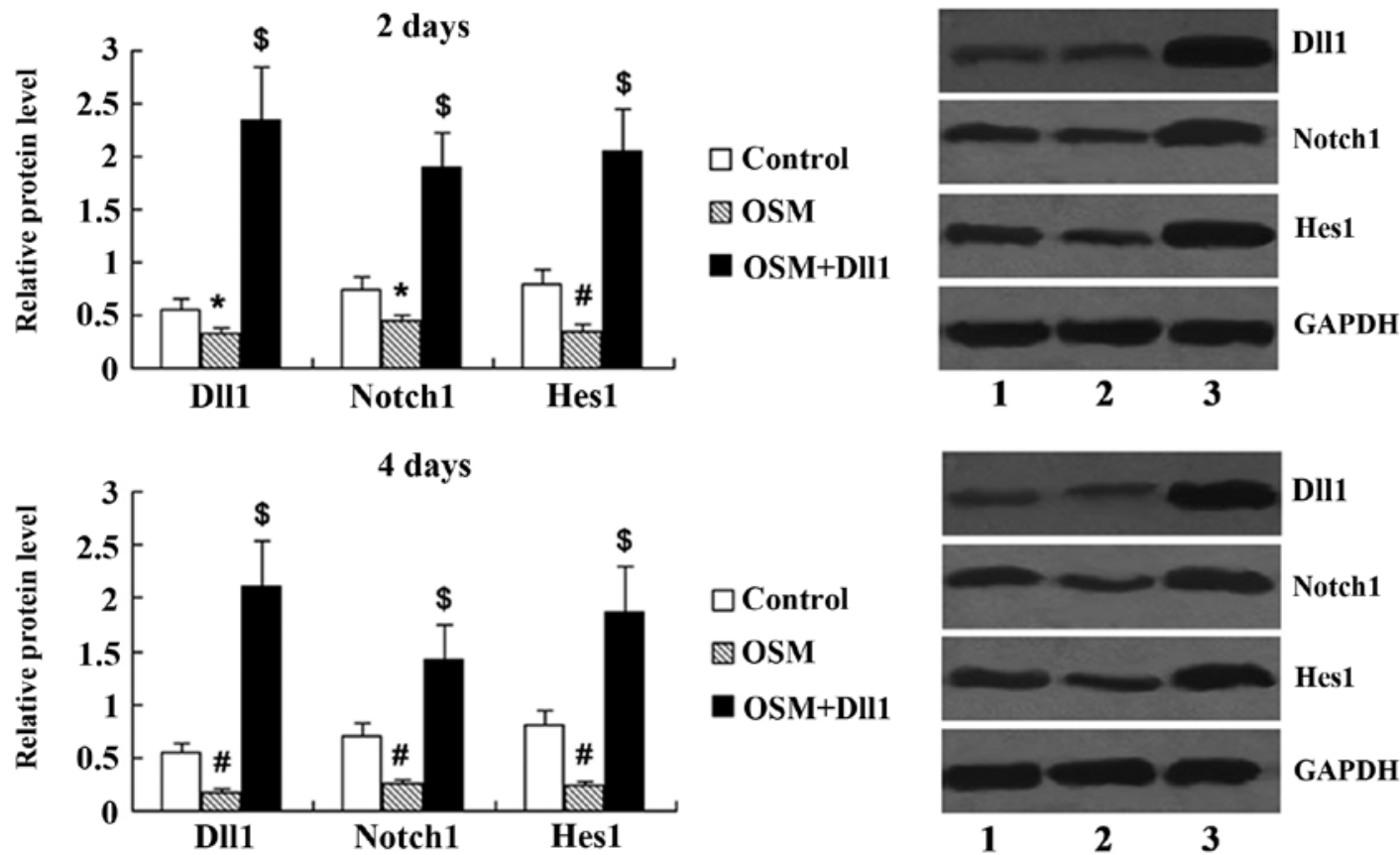

Figure 6. Expression of Notch signaling molecules in MC3T3-E1 cells transfected with the Dll1 overexpression vector followed by incubation with OSM for 2 and 4 days. " $\mathrm{P}<0.05$ and ${ }^{\#} \mathrm{P}<0.01$ vs. control group; ${ }^{\$} \mathrm{P}<0.01$ vs. OSM group. Lane 1, control; lane 2, OSM; lane 3, OSM + Dll1. OSM, oncostatin M; Dl11, Delta-like 1; Notch1, Notch homolog 1; Hes1, Hes family bHLH transcription factor 1.

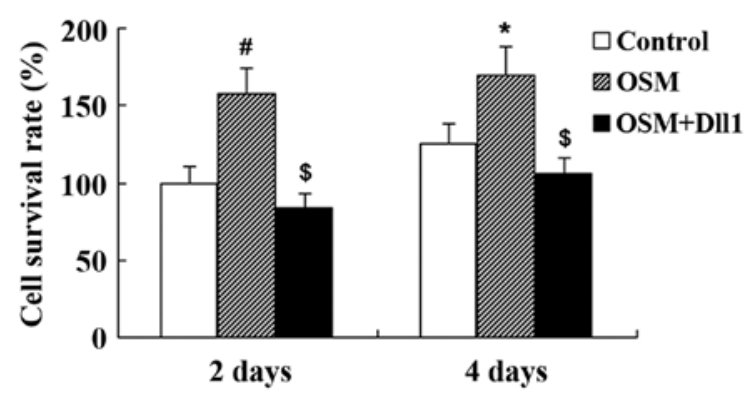

Figure 7. Activation of Notch signaling attenuates the effects of OSM on MC3T3-E1 cell proliferation. ${ }^{*} \mathrm{P}<0.05$ and ${ }^{\#} \mathrm{P}<0.01$ vs. control group; ${ }^{\$} \mathrm{P}<0.01$ vs. OSM group. OSM, oncostatin M; Dl11, Delta-like 1.

the Dll1 overexpression vector for $48 \mathrm{~h}$, the expression levels of Dll1, Notch1 and Hes1 in the MC3T3-E1 cells treated with OSM for 2 and 4 days were determined by western blot analysis. The protein expression of Dll1 was significantly upregulated in the OSM + Dll1 group compared with the OSM group $(\mathrm{P}<0.01$; Fig. 6). Notch1 and Hes1 expression was also significantly increased in the MC3T3-E1 cells transfected with the Dll1 overexpression vector $(\mathrm{P}<0.01)$.

We then investigated whether the activation of Notch signaling affects the OSM-induced MC3T3-E1 cell proliferation. Cell viability was assessed by MTT assay following treatment with $50 \mathrm{ng} / \mathrm{ml}$ OSM. We found that cell viability was significantly increased in the OSM-treated group compared with the control group $(\mathrm{P}<0.01)$. However, the activation of Notch signaling led to a decrease in OSM-induced cell proliferation; cell viability was significantly decreased in the OSM + Dll1 group compared with the OSM group ( $\mathrm{P}<0.01 ;$ Fig. 7).

Activation of Notch signaling attenuates the effects of OSM on MC3T3-E1 cell differentiation. The MC3T3-E1 cells were 


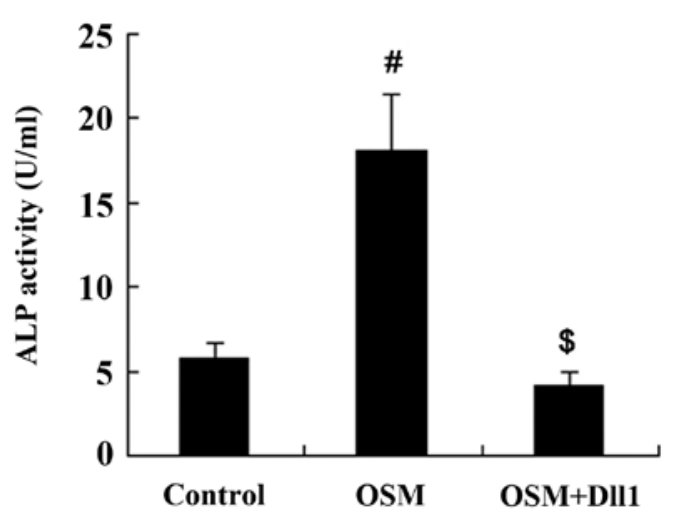

Figure 8. Activation of Notch signaling attenuates the effects of OSM on ALP activity. ${ }^{\#} \mathrm{P}<0.01$ vs. control group; ${ }^{\$} \mathrm{P}<0.01$ vs. OSM group. OSM, oncostatin $\mathrm{M}$; ALP, alkaline phosphatase; Dl11, Delta-like 1.
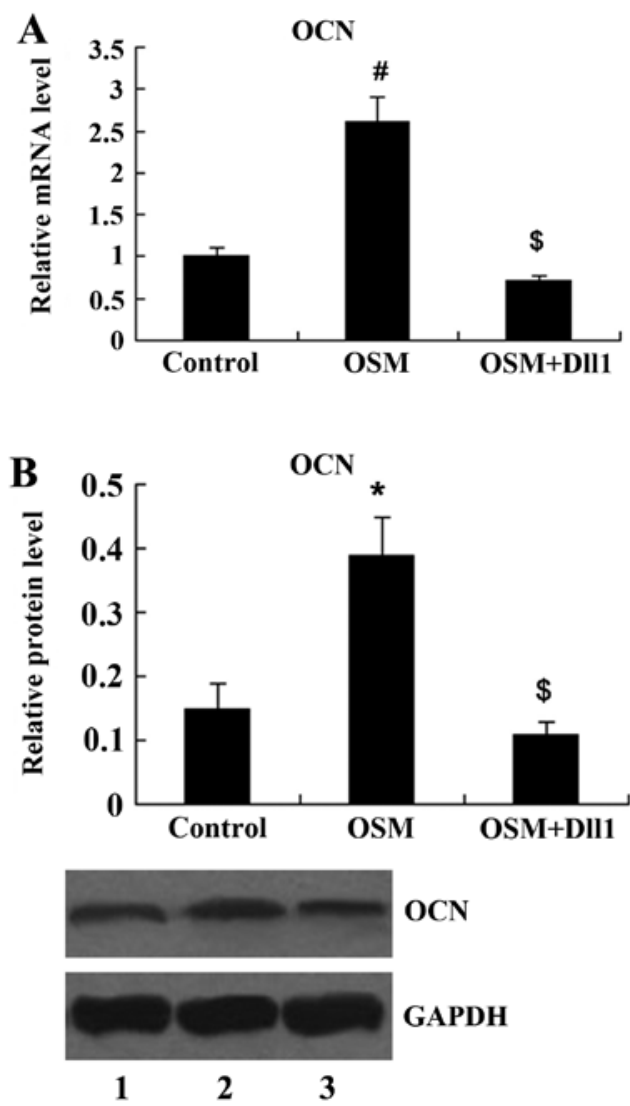

Figure 9. Activation of Notch signaling attenuates the effects of OSM on OCN (A) mRNA and (B) protein expression." $\mathrm{P}<0.05$ and ${ }^{\mathrm{P}} \mathrm{P}<0.01$ vs. control group; ${ }^{\$} \mathrm{P}<0.01$ vs. OSM group. Lane 1, control; lane 2, OSM; lane 3, OSM + Dll1 OSM, oncostatin M; OCN, osteocalcin; Dll1, Delta-like 1.

treated with $50 \mathrm{ng} / \mathrm{ml}$ OSM for 3 days following transfection with the Dll1 overexpression vector. Subsequently, the cells were harvested for the measurement of ALP activity and OCN expression. The results revealed that both ALP activity and OCN expression in the MC3T3-E1 cells were increased following treatment with OSM. However, the activation of Notch signaling attenuated the effects of OSM on MC3T3-E1 cell differentiation; compared with the OSM group, both ALP activity and OCN expression were decreased in the OSM + Dll1 group $(\mathrm{P}<0.01$; Figs. 8 and 9).

\section{Discussion}

Previous studies have suggested that OSM contributes to the pathogenesis of OA. It has been demonstrated that OSM overexpression in the mouse knee joint induces changes to the joint that resemble $\mathrm{OA}$, including cartilage destruction and periosteal bone formation similar to osteophytes $(14,15)$. In the present study, we found that OSM was detected in the synovial tissue of the knee joint, and the expression level of OSM was higher in patients with knee OA compared with the controls. This suggests that OSM contributes to the development of knee OA.

OSM has been shown to stimulate osteoblast differentiation by stromal cells and to reduce the ability of stromal cells to differentiate into adipocytes $(16,17)$. It also drives the formation of osteoclasts, particularly under pathological conditions. It has been documented that osteoblasts play essential roles in bone remodeling in arthritis (18). In the present study, we performed in vitro experiments using MC3T3-E1 cells (mouse osteoblasts) to investigate the role of OSM on MC3T3-E1 cell proliferation and differentiation. It was demonstrated that OSM affected MC3T3-E1 cell proliferation in a concentration-dependent manner. The results of specific ALP activity and OCN, as indicators of osteogenic differentiation revealed that OSM induced MC3T3-E1 differentiation. These findings demonstrate that OSM induces bone formation by increasing osteoblast cell proliferation and differentiation.

Notch signaling is a highly conserved pathway (19) regulated by interactions between neighboring cells. It is crucial for the regulation of a number of cellular processes, including proliferation, differentiation, apoptosis and cell death during embryogenesis, as well as the development and renewal of adult tissues $(20,21)$. Notch signaling has also been implicated in regulating articular cartilage homeostasis during adult life $(22,23)$. It has been demonstrated that several Notch signaling molecules are abundantly expressed in OA (23), and Notch signaling is activated in OA cartilage (24). Our findings suggest a connection between OSM and Notch signaling. We found that the expression of Notch ligand, receptor and target gene, including Dll1, Notch1 and Hes1 was decreased following treatment with OSM in a time-dependent manner in the MC3T3-E1 cells. We then investigated the hypothesis that Notch signaling plays a role in the effects of OSM on MC3T3-E1 cell proliferation and differentiation.

Dll1 is able to activate the Notch1 receptor, leading to the activation of endogenous Hes1 genes (25) and several studies have demonstrated the inhibitory effects of Notch1 on osteoblastic cell differentiation (26-28). In the present study, the Dll1 overexpression vector was used to activate Notch signaling and the results revealed that the activation of Notch signaling attenuated the effects of OSM on MC3T3-E1 cell proliferation and differentiation.

In conclusion, elevated levels of OSM in the synovial tissue may induce bone formation by increasing osteoblast cell proliferation and differentiation. OSM exerts an inhibitory effect to Notch signaling, and the OSM-induced MC3T3-E1 proliferation and differentiation may be reversed by the activation of Notch signaling. It may prove useful if future directions in 
the research and treatment of OA focus on the upstream and downstream molecules of Notch signaling that modulate the initiation and progression of $\mathrm{OA}$.

\section{References}

1. Quilty B, Tucker M, Campbell R and Dieppe P: Physiotherapy, including quadriceps exercises and patellar taping, for knee osteoarthritis with predominant patello-femoral joint involvement: Randomized controlled trial. J Rheumatol 30: 1311-1317, 2003

2. Guccione AA, Felson DT, Anderson JJ, Anthony JM, Zhang Y, Wilson PW, Kelly-Hayes M, Wolf PA, Kreger BE and Kannel WB The effects of specific medical conditions on the functional limitations of elders in the Framingham Study. Am J Public Health 84: 351-358, 1994

3. Woolf AD and Pfleger B: Burden of major musculoskeletal conditions. Bull World Health Organ 81: 646-656, 2003.

4. Parmet S, Lynm C and Glass RM: JAMA patient page. Osteoarthritis of the knee. JAMA 289: 1068, 2003.

5. Lin CW, Taylor D, Bierma-Zeinstra SM and Maher CG: Exercise for osteoarthritis of the knee. Phys Ther 90: 839-842, 2010.

6. Fernandes JC, Martel-Pelletier J and Pelletier JP: The role of cytokines in osteoarthritis pathophysiology. Biorheology 39: 237-246, 2002

7. Zarling JM, Shoyab M, Marquardt H, Hanson MB, Lioubin MN and Todaro GJ: Oncostatin M: A growth regulator produced by differentiated histiocytic lymphoma cells. Proc Natl Acad Sci USA 83: 9739-9743, 1986.

8. Tanaka $\mathrm{M}$ and Miyajima A: Oncostatin M, a multifunctional cytokine. Rev Physiol Biochem Pharmacol 149: 39-52, 2003.

9. Brounais B, David E, Chipoy C, et al: Long term oncostatin M treatment induces an osteocyte-like differentiation on osteosarcoma and calvaria cells. Bone 44: 830-839, 2009

10. Jorcyk CL, Holzer RG and Ryan RE: Oncostatin M induces cell detachment and enhances the metastatic capacity of T-47D human breast carcinoma cells. Cytokine 33: 323-336, 2006.

11. Brounais B, Chipoy C, Mori K, Charrier C, Battaglia S, Pilet P, Richards CD, Heymann D, Rédini F and Blanchard F: Oncostatin $\mathrm{M}$ induces bone loss and sensitizes rat osteosarcoma to the antitumor effect of Midostaurin in vivo. Clin Cancer Res 14: 5400-5409, 2008.

12. Lisignoli G, Piacentini A, Toneguzzi S, Grassi F, Cocchini B, Ferruzzi A, Gualtieri G and Facchini A: Osteoblasts and stromal cells isolated from femora in rheumatoid arthritis (RA) and osteoarthritis (OA) patients express IL-11, leukaemia inhibitory factor and oncostatin M. Clin Exp Immunol 119: 346-353, 2000.

13. de Hooge AS, van de Loo FA, Bennink MB, Arntz OJ, Fiselier TJ Franssen MJ, Joosten LA, Van Lent PL, Richards CD and van den Berg WB: Growth plate damage, a feature of juvenile idiopathic arthritis, can be induced by adenoviral gene transfer of oncostatin M: A comparative study in gene-deficient mice. Arthritis Rheum 48: 1750-1761, 2003.

14. Langdon C, Kerr C, Hassen M, Hara T, Arsenault AL and Richards CD: Murine oncostatin M stimulates mouse synovial fibroblasts in vitro and induces inflammation and destruction in mouse joints in vivo. Am J Pathol 157: 1187-1196, 2000.
15. de Hooge AS, van de Loo FA, Bennink MB, de Jong DS, Arntz OJ, Lubberts E, Richards CD and vandDen Berg WB: Adenoviral transfer of murine oncostatin $\mathrm{M}$ elicits periosteal bone apposition in knee joints of mice, despite synovial inflammation and up-regulated expression of interleukin- 6 and receptor activator of nuclear factor-kappa B ligand. Am J Pathol 160: 1733-1743, 2002.

16. Walker EC, McGregor NE, Poulton IJ, Pompolo S, Allan EH, Quinn JM, Gillespie MT, Martin TJ and Sims NA: Cardiotrophin-1 is an osteoclast-derived stimulus of bone formation required for normal bone remodeling. J Bone Miner Res 23: 2025-2032, 2008.

17. Walker EC, McGregor NE, Poulton IJ, et al: Oncostatin M promotes bone formation independently of resorption when signaling through leukemia inhibitory factor receptor in mice. J Clin Invest 120: 582-592, 2010.

18. Lisignoli G, Toneguzzi S, Pozzi C, Piacentini A, Riccio M, Ferruzzi A, Gualtieri G and Facchini A: Proinflammatory cytokines and chemokine production and expression by human osteoblasts isolated from patients with rheumatoid arthritis and osteoarthritis. J Rheumatol 26: 791-799, 1999.

19. Richards GS and Degnan BM: The dawn of developmental signaling in the metazoa. Cold Spring Harb Symp Quant Biol 74: 81-90, 2009.

20. Calvi LM, Adams GB, Weibrecht KW, et al: Osteoblastic cells regulate the haematopoietic stem cell niche. Nature 425: 841-846, 2003.

21. Yoon K and Gaiano N: Notch signaling in the mammalian central nervous system: Insights from mouse mutants. Nat Neurosci 8: 709-715, 2005.

22. Sassi N, Laadhar L, Driss M, Kallel-Sellami M, Sellami S and Makni S: The role of the Notch pathway in healthy and osteoarthritic articular cartilage: From experimental models to ex vivo studies. Arthritis Res Ther 13: 208, 2011.

23. Karlsson C, Brantsing C, Egell S and Lindahl A: Notch1, Jagged1, and HES5 are abundantly expressed in osteoarthritis. Cells Tissues Organs 188: 287-298, 2008.

24. Sassi N, Laadhar L, Mahjoub M, Driss M, Zitouni M, Benromdhane K, Makni S and Sellami S: Expression of Notch family members in cultured murine articular chondrocytes. Biotech Histochem 84: 313-320, 2009.

25. Jarriault S, Le Bail O, Hirsinger E, Pourquié O, Logeat F, Strong CF, Brou C, Seidah NG and Israël A: Delta-1 activation of notch-1 signaling results in HES-1 transactivation. Mol Cell Biol 18: 7423-7431, 1998.

26. Sciaudone M, Gazzerro E, Priest L, Delany AM and Canalis E: Notch 1 impairs osteoblastic cell differentiation. Endocrinology 144: 5631-5639, 2003.

27. Zamurovic N, Cappellen D, Rohner D and Susa M: Coordinated activation of notch, Wnt, and transforming growth factor-beta signaling pathways in bone morphogenic protein 2-induced osteogenesis. Notch target gene Heyl inhibits mineralization and Runx2 transcriptional activity. J Biol Chem 279: 37704-37715, 2004.

28. Bai S, Kopan R, Zou W, Hilton MJ, Ong CT, Long F, Ross FP and Teitelbaum SL: NOTCH1 regulates osteoclastogenesis directly in osteoclast precursors and indirectly via osteoblast lineage cells. J Biol Chem 283: 6509-6518, 2008. 